\title{
PENATAAN KORIDOR KAWASAN SEKUMPUL MARTAPURA SEBAGAI WISATA RELIGI
}

\author{
Meidina Kartika Hadi \\ Program Studi Teknik Arsitektur Fakultas Teknik Universitas Lambung Mangkurat \\ meidinakarthadi@gmail.com
}

\author{
Gusti Novi Sarbini \\ Program Studi Teknik Arsitektur Fakultas Teknik Universitas Lambung Mangkurat \\ gustinovi@ulm.ac.id
}

\begin{abstract}
ABSTRAK
Kawasan Sekumpul Martapura yang diakui oleh Dinas Pariwisata Kabupaten Banjar sebagai Kawasan Wisata Religi makin tahun makin banyak pengunjungnya. Pertumbuhan kuantitas pengunjung Sekumpul Martapura dengan jumlah yang fantastis selalu memenuhi jalanan khususnya daerah Martapura dan Banjarbaru. Aktivitas tahunan, bulanan bahkan mingguan membuat Jalan Sekumpul selalu ramai peziarah. Hal tersebut memicu lingkungan sekitarnya menjadi aktif dalam segi ekonomi. Tempat yang dipopulerkan oleh K.H Abdul Ghani atau yang biasa dikenal dengan sebutan Guru Sekumpul kini terisi banyak aktivitas, namun, keadaan fisik kawasan belum mendukung baik turis maupun warga lokal. Jalan yang macet, pedestrian yang tidak tertata, hingga gersangnya kawasan yang kurang peneduh patut ditata kembali agar tidak menyia-nyiakan potensi dari kawasan yang sudah ada. Untuk mengatasi permasalahan tersebut, diterapkan konsep walkable place yang menerapkan metode sense of place beserta 3 aspeknya, yaitu form, image, dan activities. Konsep walkable place dinilai sesuai dan applicable untuk Penataan Koridor Kawasan Sekumpul Martapura, menjawab bagaimana mengatasi permasalahan fisik kawasan dengan pelebaran jalan, tanpa mengabaikan eksisting kawasan, menambah amenities, menciptakan ruang-ruang positif, mengoptimalkan potensi kawasan sebagai wisata religi dan komersial, serta memperkuat sense of place Sekumpul itu sendiri. Identitas dan karakter yang sudah terbentuk di Sekumpul tidak dapat diabaikan dan diganti begitu saja, maka inti dari desain penataan ini adalah menjaga yang sudah ada, dan mengembangkan untuk pengguna.
\end{abstract}

Kata Kunci: Penataan, Wisata Religi, Sekumpul, Walkable Place, Sense Of Place, Martapura.

\begin{abstract}
Sekumpul, Martapura is acknowledged as a religious tourism destination by Banjar District's Department of Tourism. Its number of visitors increase rapidly each year, crowding the streets especially in Martapura and Banjarbaru. Yearly, monthly, and even weekly events attract a lot of pilgrims, which boost the economic sector of the local community. This location, which was popularized by K.H. Abdul Ghani (also known as Guru Sekumpul) has now been filled with many activities. Unfortunately, the physical condition of Sekumpul can no longer accommodate the locals nor the pilgrims. The problem of traffic jams, discomfort and unsafety of pedestrians, and even the dryness of the area must be given solutions so that existing facilities will not go to waste. To solve these problems, the "walkable place" concept is applied, which uses the "sense of place" method with its 3 aspects (form, image, and activities). The walkable place concept is considered suitable and
\end{abstract}


applicable for Rearrangement of Sekumpul Corridor, Martapura, solving problems of the physical conditions by road widening while still considering the existing conditions, adding amenities, creating positive spaces, optimizing the potential of the religious and commercial sectors, and also strengthening Sekmpul's sense of place. The identity and character already formed in Sekumpul cannot be ignored and changed, therefore this design conserves while also developing for the good of the users.

Keyword: Rearrangement, Religious Tourism, Walkable Place, Sense of Place, Martapura.

\section{PENDAHULUAN}

Kawasan Sekumpul Martapura merupakan kawasan historical yang mulai terkenal dengan sebutan Sekumpul pada tahun 1989. Dipopulerkan oleh ulama besar K.H. Muhammad Zaini Abdul Ghani (Wikipedia, 2018). Semenjak hijrahnya pengajian yang beliau isi dalam era baru syiar islam di Martapura, sebutan Sekumpul menjadi tidak asing di kalangan masyarakat. Sebutan Sekumpul itu sendiri juga menjadi panggilan masyarakat dalam menghormati ulama tersebut. Setelah 14 tahun Guru Sekumpul wafat, kawasan Sekumpul semakin ramai pengunjung yang berasal dari berbagai daerah di Kalimantan bahkan luar pulau, khususnya pada hari haul Abah Guru yang diadakan setiap tahun.

Dalam beberapa dekade terakhir, fenomena akan wisata religi oleh komunitas muslim berada dalam titik yang sangat ramai. Dibuktikan dengan meningkatnya aktivitas-aktivitas seperti berziarah ke makam kyai atau ulama yang dipercayai memiliki keunggulan dalam hal spiritual (Latifah etc, 2018). Berdasarkan data dari Dinas Pariwisata Kabupaten Banjar, Sekumpul Martapura telah menjadi salah satu destinasi wisata religi di Kabupaten Banjar karena banyaknya pengunjung dari berbagai kota (Peraturan Daerah Kabupaten Banjar, 2013). Sekumpul merupakan satu dari 11 destinasi objek wisata di Kabupaten Banjar yang telah diresmikan dan diakui sebagai objek wisata. Dengan data jumlah pengunjung yang semakin meningkat pertahunnya sebagaimana yang tertera pada tabel berikut.

\begin{tabular}{cc}
\hline Tahun & Jumlah Pengunjung \\
\hline 2015 & 483,727
\end{tabular}

2016

2017

2018

$3,226,496$

$4,479,993$

$5,068,238$

Gambar 1 Pertumbuhan Jumlah Pengunjung

(Dinas Pariwisata Kabupaten Banjar, 2018)

Dari tabel diatas, pengunjung Sekumpul Martapura mengalami peningkatan drastis hingga kurang lebih 900\% berdasarkan data pengunjung dari tahun 2015 sampai 2018. Peningkatan pengunjung Sekumpul Martapura juga diprediksi oleh Posko Induk Sekumpul akan semakin meningkat pada tahun-tahun berikutnya. Hal tersebut membuat kawasan Sekumpul diakui sebagai pusat daerah dan aktivitas keagamaan nasional juga pariwisata budaya serta destinasi warisan budaya (Peraturan Daerah Kabupaten Banjar Nomor 3 Tahun 2013).

\section{Jumlah Pengunjung Objek Wisata Kabupaten Banjar 4 Tahun Terakhir}

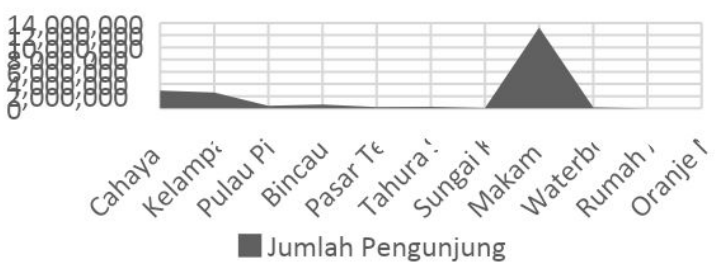

Gambar 2 Pertumbuhan Jumlah Pengunjung Wisata Kabupaten Banjar 4 Tahun Terakhir (Dinas Pariwisata Kabupaten Banjar, 2019) 
Jika dibandingkan dengan objek wisata lainnya di Kabupaten Banjar, Makam Guru Sekumpul memiliki pengunjung 65\% unggul dan menjadi wisata nomor 1 dari jumlah total pengunjung keseluruhan pada 11 objek wisata di Kabupaten Banjar. Dengan total pengunjung sebanyak 13.258.454 dari 20.593.898 pengunjung keseluruhan wisata di Kabupaten Banjar selama 4 tahun terakhir.

Namun, berdasarkan hasil survey lapangan dan wawancara, unggulnya Sekumpul sebagai objek wisata di Kabupaten Banjar belum didukung oleh lingkungan dan infrastruktur yang memadai. Walaupun sekarang sudah mulai direncanakan beberapa perbaikan pada hal-hal yang dianggap vital seperti drainase oleh Dinas PUPR Cipta Karya, bagi mayoritas responden saat wawancara merasa masih perlu peningkatan terutama dalam hal kenyamanan dan keamanan khususnya pada pengguna koridor yang aktif seperti pedagang, pengendara bermotor, serta pejalan kaki di jalan utama.

Selain wawancara, penulis juga melakukan observasi langsung di lapangan yang membuktikan perlunya perbaikan pada sekumpul.

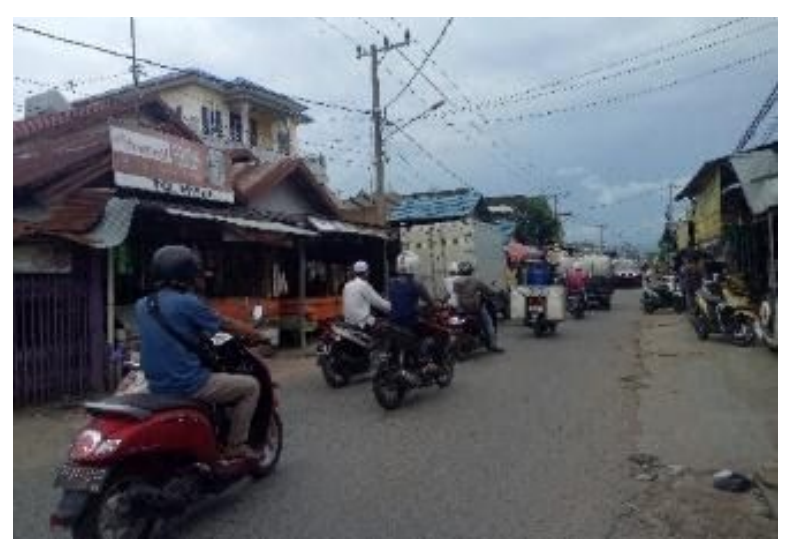

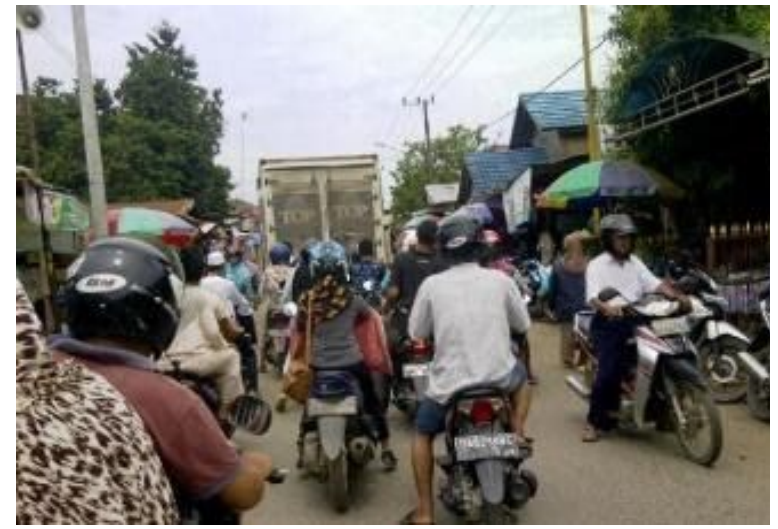

Gambar 3 Sirkulasi Eksisting (Banjarmasin Post, 2014 (kanan)
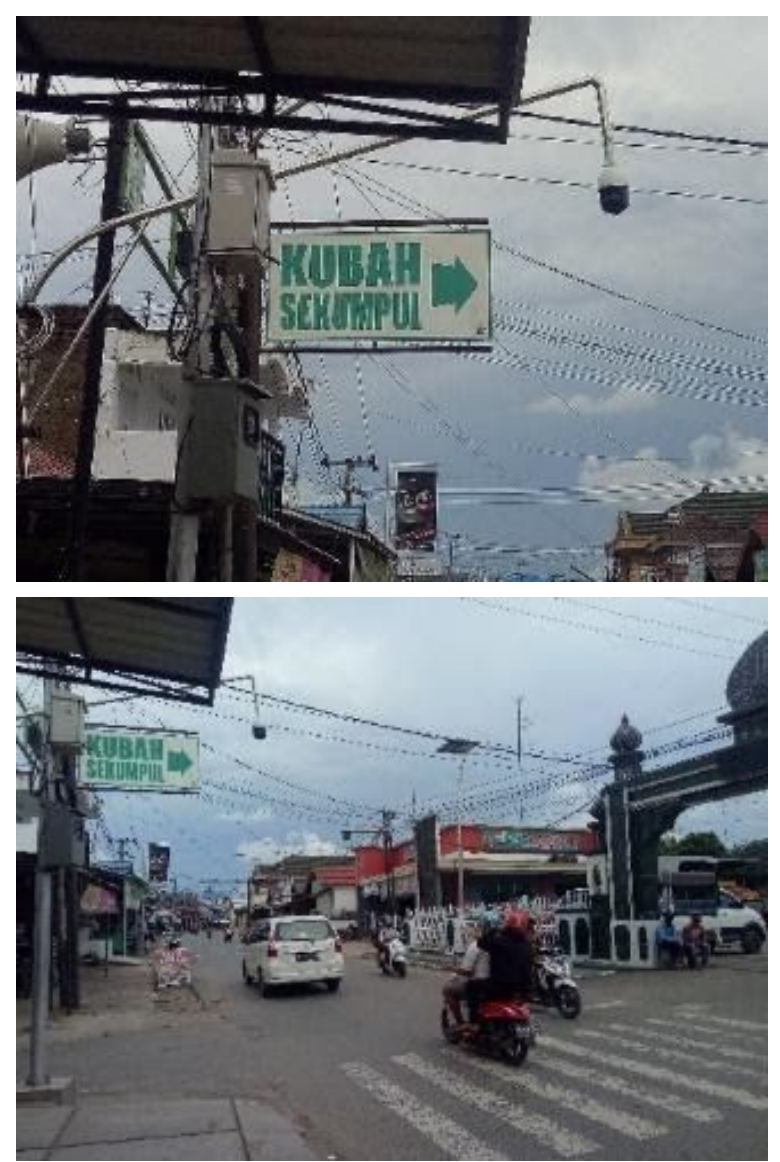

Gambar 4 Signage Eksisting

Signage menuju Kubah Sekumpul Martapura terletak berseberangan dengan gate masuk ke Kubah Sekumpul dengan keterangan "KUBAH SEKUMPUL." Hal ini dinilai belum terlalu membantu turis dalam 
menemukan Kubah Sekumpul, karena belum lengkap dan begitu jelas (Latifah, etc 2018).
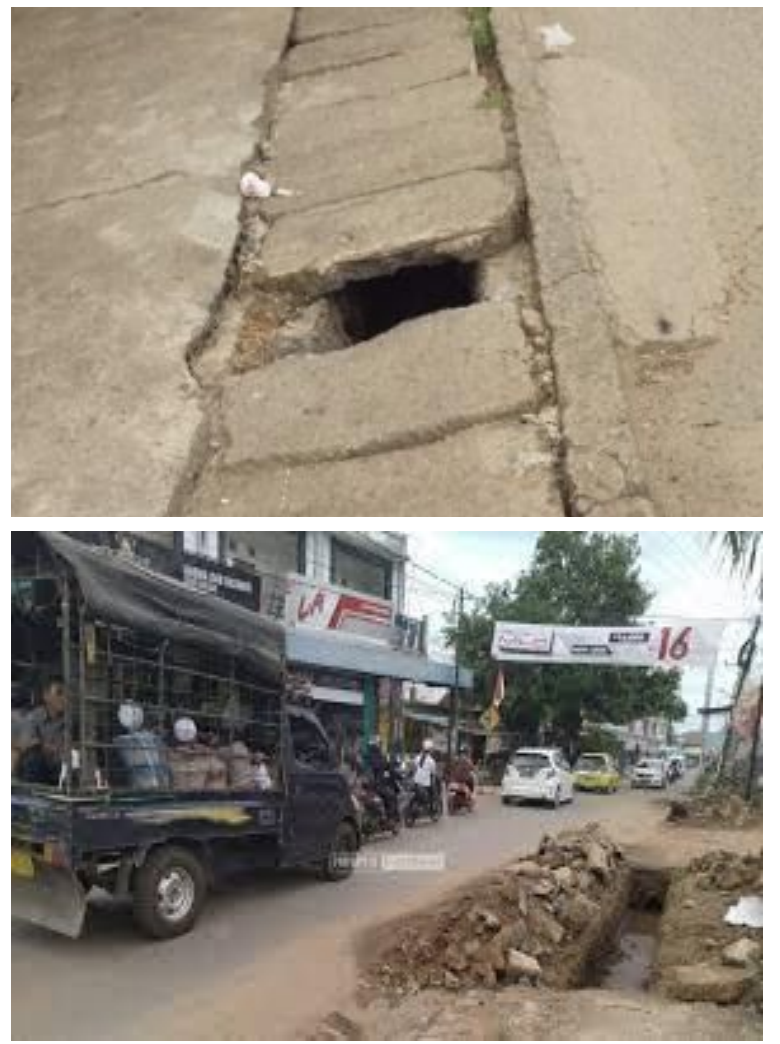

Gambar 5 Pedestrian Eksisting (Koran Banjar, 2018 (kanan)

Kondisi pedestrian di Sekumpul Martapura sangat kecil dengan lebar kurang lebih 1 meter, sekaligus sebagai penutup drainase. Sayangnya, pada beberapa titik drainase dibiarkan terbuka dan pejalan kaki hanya berbagi jalur dengan pengendara bermotor. Sebagian lain menutup drainase dengan kayu, dan sebagian lain didapati pedestrian dengan keadaan rusak (Lihat pada gambar 7 ).

Berdasarkan hasil survey lapangan, dan wawancara, potensi kawasan dari faktor sosial, faktor ekonomi dan faktor spiritual yang telah ada belum didukung oleh kondisi fisik kawasan. Kawasan yang ada sekarang dinilai belum aman, kurang nyaman khususnya bagi pejalan kaki yang aktif terlebih lagi pada waktu-waktu tertentu seperti acara haul Abah Guru Sekumpul. Sempitnya jalan dan aktivitas komersial turut mengundang kemacetan khususnya di titik-titik persimpangan. Menurut Bapak Ilyas dan Ibu Ajeng selaku pegawai Kelurahan Sekumpul Martapura mengatakan bahwa mereka mengakui adanya rencana dari pemerintah setempat untuk menata dan mengembangkan koridor Sekumpul Martapura, namun hal ini masih berupa wacana yang belum terealisasikan. Sempat beberapa kali pula dari pemerintah provinsi, bupati, kementerian PUPR dan kelurahan Sekumpul sendiri melakukan kunjungan membahas pengembangan koridor Sekumpul ini. Pengembangan yang direncanakan berupa fasilitas infrastruktur dan perbaikan jalan, drainase, pemasangan paving, pelebaran jalan dan hal-hal lain yang berkaitan. Sudah dilakukan FGD (forum group discussion) yang melibatkan warga tentang rencana tersebut, namun pemerintah merasa masih perlu melakukan penyuluhan lebih lanjut. Selain itu, rencana seperti pelebaran jalan akan memerlukan waktu lebih karena menyangkut aktivitas warga sebab berkaitan dengan pembebasan lahan. Sebagaimana yang kita ketahui kawasan Sekumpul Martapura sangat ramai akan toko-toko yang berjualan di sepanjang jalan koridor, sayangnya, banyak masyarakat yang tidak memiliki IMB (izin mendirikan bangunan) dan melanggar GSB (garis sempadan bangunan) yang ditetapkan yaitu 15 meter dari as jalan. 


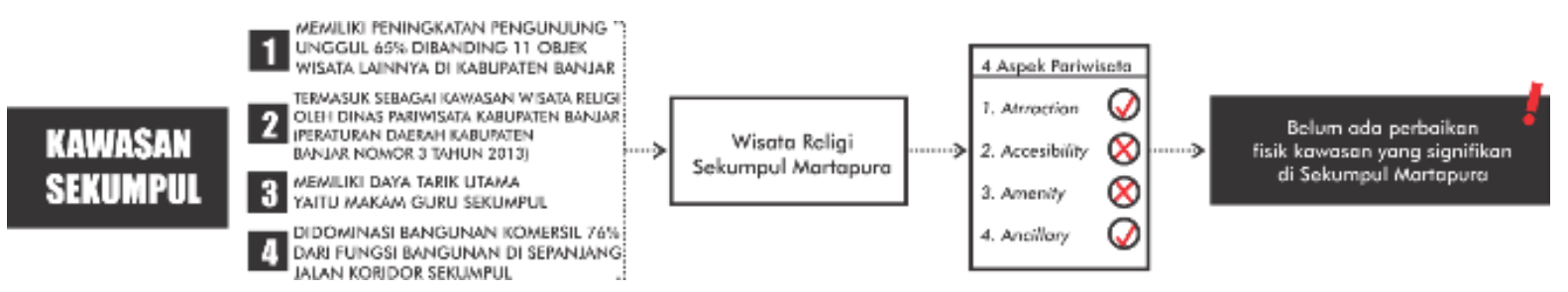

Gambar 6 Permasalahan

\section{PERMASALAHAN}

Dari analisis data, hasil survey lapangan, serta wawancara, dapat kita buktikan bahwa kawasan Sekumpul perlu penataan kawasan dengan desain yang memberi hak masyarakat akan jalan, komersial, dan tidak menghilangkan identitas Sekumpul sebagai kawasan wisata religi, namun justru memperkuatnya. Hal ini merujuk pada permasalahan arsitektural yaitu bagaimana mengoptimalkan potensi Kawasan Sekumpul Martapura sebagai wisata religi yang memberi prioritas yang sesuai dengan kebutuhan pengguna? Untuk menyelesaikan permasalahannya, maka diangkatlah judul Penataan Koridor di Kawasan Wisata Religi Sekumpul Martapura.

\section{TINJAUAN PUSTAKA}

\section{A. Tinjauan Arsitektural}

Kawasan adalah sebuah tempat yang mempunyai ciri serta mempunyai kekhususan untuk menampung kegiatan manusia berdasarkan kebutuhannya dan setiap tempat yang mempunyai ciri dan identitas itu akan lebih mudah untuk dicari ataupun ditempati untuk lebih melancarkan segala hal yang berhubungan dengan kegiatannya (Purwantiasning dkk, 2013). Di Dalam kawasan, terdapat pula jalan penghubung yang menjadi jalur utama dalam kawasan tersebut yang disebut koridor. Koridor biasanya ditumbuhi banguna-bangunan yang berderet memanjang di sepanjang ruas jalan tersebut pada sisi kiri dan kanannya (Moughtin, 1992:41).
Tata ruang kota adalah wujud struktural dari pola pemanfaatan ruang yang direncanakan maupun tidak. Kondisi penduduk secara sosial maupun ekonomi sangat terkait erat dengan penataan ruang kota, pengelolaan lingkungan dan sumber daya alam yang ada. Karena itu penataan ruang tersebut sangat berpengaruh pada sumber daya manusia yang berinteraksi dengan tempat, waktu dan budaya masyarakat setempat. Dalam penataan kota, ada beberapa unsur atau elemen yang menjadi pembentuk dalam tatanan kota tersebut, dimana elemen-elemen tersebut sangatlah berpengaruh terhadap pola dan bentuk kota (Zuhri, 2012).

Menurut Sihite, (dalam Marpaung dan Bahar, 2000) mendefinisikan pariwisata adalah suatu perjalanan yang dilakukan orang untuk sementara waktu, yang diselenggarakan dari suatu tempat ke tempat lain meninggalkan tempatnya semula, dengan suatu perencanaan dan dengan maksud bukan untuk berusaha atau mencari nafkah di tempat yang dikunjungi, tetapi semata- mata untuk menikmati kegiatan pertamasyaan dan rekreasi atau untuk memenuhi keinginan yang beraneka ragam. Menurut UU Nomor 9 Tahun 1990 Bab I Pasal 1, mendefinisikan kepariwisataan adalah segala sesuatu yang berhubungan dengan penyelenggaraan pariwisata. Artinya semua kegiatan dan urusan yang ada kaitannya dengan perencanaan, pengaturan, pelaksanaan, pengawasan, pariwisata baik yang dilakukan oleh pemerintah, pihak swasta dan masyarakat disebut kepariwisataan.

Wisata religi atau wisata pilgrim sedikit banyak dikaitkan dengan adat istiadat, agama dan kepercayaan umat atau 
kelompok atau pula masyarakat. Kegiatan wisata ini banyak dilakukan secara perorangan maupun rombongan ke tempat-tempat suci, atau pula ke makam-makam orang besar atau pemimpin yang diagungkan, atau ke bukit dan gunung yang dianggap keramat, serta pemakaman tokoh pemimpin yang dikenal sebagai tokoh ajaib penuh legenda (Pendit, 2006).

Dalam beberapa dekade terakhir, fenomena akan wisata religious oleh komunitas muslim berada dalam titik yang sangat ramai. Dibuktikan dengan meningkatnya aktivitas-aktivitas seperti berziarah ke makam kyai atau ulama yang dipercayai memiliki keunggulan dalam hal spiritual. Sebagaimana yang terjadi pada makam K. H. Abdul Ghani Al-Banjari yang berlokasi di Sekumpul Martapura Kalimantan Selatan. Fenomena wisata religious ini membuktikan pula bahwa syiar islam berkembang pesat di daerah Kalimantan Selatan. Hal tersebut yang membuat Kota Martapura kaya dengan nilai-nilai islam. Khususnya, pada bulan Ramadhan dan peringatan hari meninggalnya Guru Sekumpul, intensitas peziarah yang datang meningkat pesat dibandingkan pada hari-hari biasanya.

\section{B. Tinjauan Konsep}

\section{Walkability}

Berjalan kaki menjadi salah satu kegiatan transportasi yang tidak membutuhkan biaya dan ramah lingkungan. Berdasarkan survei yang dilakukan oleh urban mobility for Indonesia, 12\% masyarakat memilih berjalan kaki dibandingkan menggunakan sepeda dan angkutan lingkungan tradisional seperti becak atau delman sebagai non motorized transportation ketika berpergian (Agustin, 2017). Berhubungan dengan hal ini, konsep walkability diperkenalkan sebagai salah satu indikator pengembangan kota berkelanjutan. Dengan berjalan kaki, kemacetan dan polusi udara yang dihasilkan oleh motorized transportation dapat dikurangi (Forsyth, 2015; Forsyth \& Southworth, 2008).

Menurut Victoria Transport Policy Institute (2014) mengemukakan walkability memperhitungkan beberapa parameter, yakni kualitas fasilitas, konektivitas jalur, kondisi jalan, pola tata guna lahan, dukungan masyarakat, kenyamanan, serta rasa aman saat berjalan. Walkability dapat dievaluasi pada skala lokasi, ruas jalan, ataupun skala lingkungan. Secara umum walkability memperhitungkan sebagai berikut:

a. Kualitas jaringan jalur pejalan kaki (trotoar, penyeberangan)

b. Konektivitas jaringan jalur pejalan kaki (seberapa baik trotoar dan jalur pejalan kaki lainnya saling terhubung, dan seberapa baik pejalan kaki dapat mengakses tempat tujuan secara langsung).

c. Keamanan (seberapa aman yang dirasakan orang saat berjalan).

d. Kepadatan dan aksesibilitas (jarak antara lokasi destinasi umum, seperti rumah, toko, sekolah, dan taman)

\section{METODE}

Tujuan rancangan ini adalah untuk menata kembali koridor utama kawasan sekumpul dengan memperkuat identitasnya sebagai kawasan wisata religi yang menerapkan walkability sebagai landasan dalam rangka optimalisasi dalam mencapai kawasan yang livable. Tujuan dan permasalahan dari Sekumpul Martapura dapat dicapai dan dituntaskan dengan menerapkan metode sense of place yang merupakan sebuah bentuk pemahaman yang membentuk keterkaitan antara tempat dan orang yang berada didalamnya. Menciptakan 'rasa' yang dibentuk antara 'place' dan 'people' yang terbentuk sesuai persepsi masing-masing orang yang berada didalamnya. Dengan penerapan metode ini, 
orang-orang yang berada di dalam kawasan Sekumpul Martapura dapat merasakan berada di kawasan permukiman komersial sekaligus wisata religi dengan menyesuaikan permasalahan eksisting kawasan Sekumpul sendiri.

\section{PEMBAHASAN}

\section{A. Analisis Kawasan Sekumpul}

Penelitian diadakan pada tahun 2019 di sepanjang koridor Sekumpul Martapura dengan Panjang 2.01 KM sebagaimana yang ditampilkan pada gambar. Dengan batasan 1 blok bangunan yang kurang lebih memiliki jarak 50 meter dari jalan utama, dan hal yang sama juga demikian pada sisi yang satunya. Untuk penelitian analisis tapak, penulis membagi koridor menjadi 6 segmen sebagaimana yang tertera pada gambar.
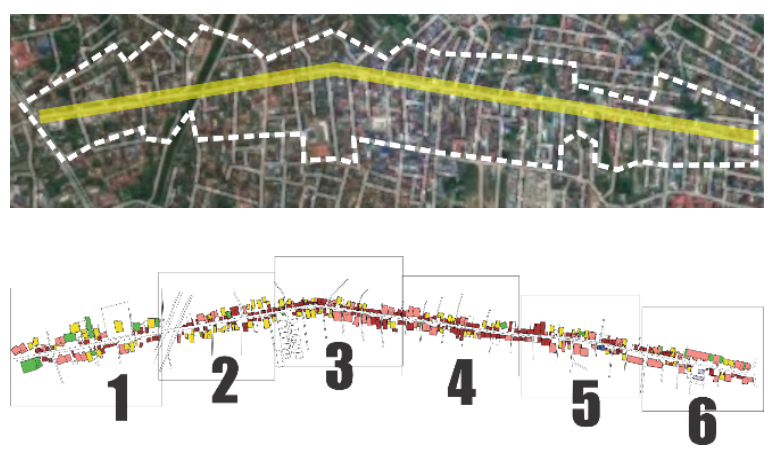

Gambar 7 Site Eksisting

\section{B. Konsep Programatik}

Berdasarkan permasalahan yang ada, dipilihlah konsep walkable place sebagai landasan dalam menyelesaikan permasalahan kawasan Sekumpul Martapura yang macet dan tidak teraturnya prioritas pengguna. Yang ingin dicapai dalam kawasan Sekumpul Martapura pada dasarnya adalah segala hal-hal yang mendasar, seperti keamanan, keselamatan, keberlanjutan ekonomi kawasan dan kenyamanan dalam berjalan kaki yang mana merupakan aspek-aspek dari walkability. Diciptakannya kawasan yang memperhatikan kebutuhan pengguna berdasarkan prioritasnya, khususnya pejalan kaki.

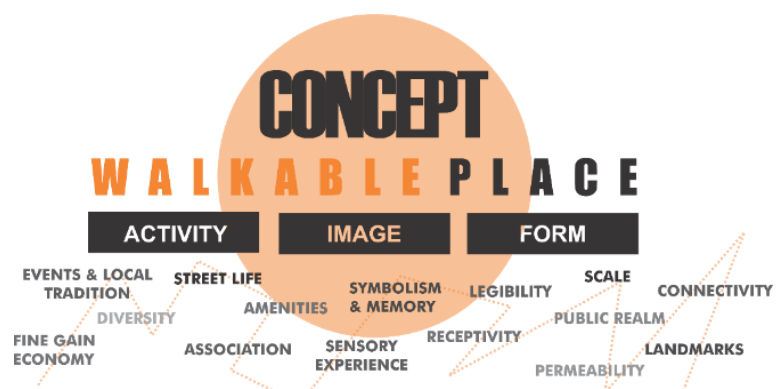

Gambar 8 Konsep Programatik

\section{Konsep Sistematik}

1. Konsep Tapak

Desain Penataan Sekumpul berorientasi pada pedestriannya, jalan sepanjang $2.01 \mathrm{KM}$ didesain dengan membuat layering, layer dibagi menjadi layer atas, dan layer bawah, mengingat desain ingin mempermudah aksesibilitas. Maka layer bawah ditata kembali pedestriannya serta ditambahkan elemen-elemen kawasan, dan layer atas difungsikan khusus untuk pejalan kaki.

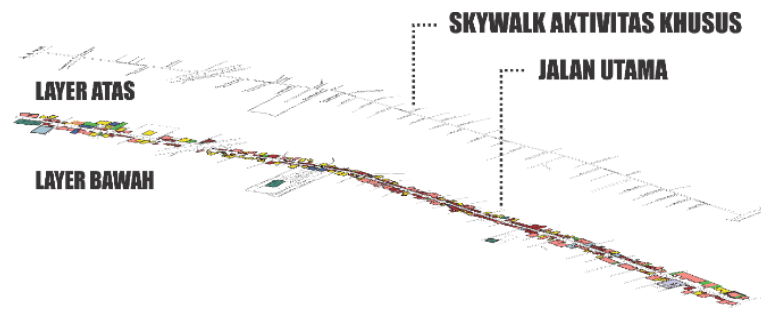

Gambar 9 Konsep Layering Tapak

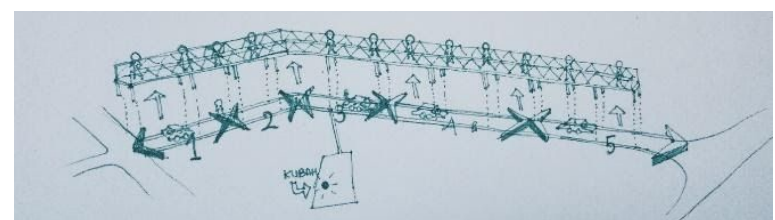


Gambar 10 Sketsa Konsep Layering Tapak

Tapak dibagi menjadi beberapa segmen, dapat dilihat lebih detail pada konsep zonasi.

\section{Konsep Zonasi}

Tapak dibagi menjadi 5 segmen, yaitu segmen zona penerimaan, segmen zona transisi, segmen zona inti dan segmen zona transisi dan penerimaan kembali. Desain difokuskan pada titik-titik yang dianggap paling krusial, yaitu zona 1, 2 dan 3 sebagai fokus desain, dapat dilihat pada titik-titik yang dipaparkan pada gambar berikut.

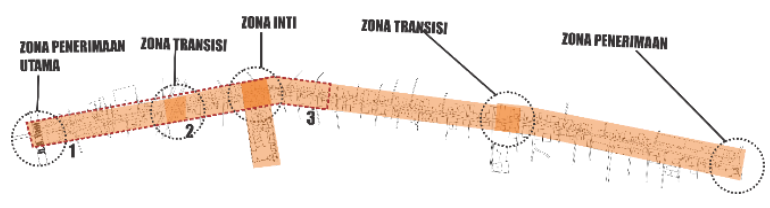

Gambar 11 Konsep Zonasi

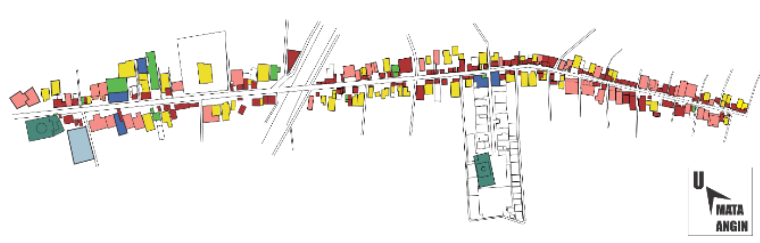

Gambar 12 Fokus Desain Zonasi

\section{Konsep Bangunan}

Skywalk dibuat sebagai strategi arsitektural yang menciptakan jalan alternatif bagi pejalan kaki. Dengan minat pejalan kaki yang tinggi di Sekumpul Martapura baik pada hari biasa maupun pada acara haul Guru Sekumpul, maka didesain sebuah jalan diatas jalan utama, yang mewadahi aktivitas di atas aktivitas.

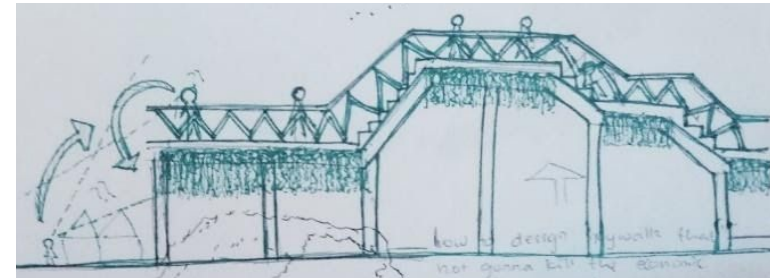

Gambar 13 Konsep Skywalk

Konsep skywalk dibuat dengan memainkan levelling lantai, untuk menciptakan keterkaitan antara ruang bawah dan ruang atas. Memainkan jarak pandang perspektif orang yang berada pada titik dia berada. Levelling yang lebih rendah pada layer atas memberikan ruang untuk dapat menangkap view aktivitas yang terjadi di layer bawah, begitu pula sebaliknya.

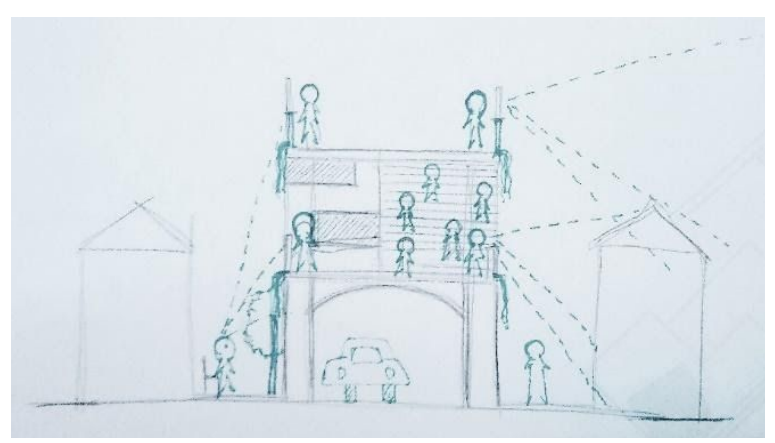

Gambar 14 Konsep Skywalk

Pada skywalk, dibuat fungsi-fungsi ruang yang fleksibel, seperti tangga, bukan hanya sebagai sirkulasi, namun juga sebagai tempat istirahat atau tempat duduk. Skywalk juga mewadahi keperluan-keperluan ruang yang penting untuk publik, seperti toilet dan menyediakan area wudhu, namun tetap mewadahi fungsi utamanya dalam memberi wadah aktivitas bagi pejalan kaki.

\section{Elemen Arsitektural}

Berdasarkan analisis massa bangunan, Sekumpul Martapura memiliki gaya arsitektur yang beragam, ada gaya 
arsitektur lokal, eropa, bahkan arsitektur arab. Konsep arsitektur bangunan skywalk itu sendiri akan mengambil icon yang sudah dilabel sebagai landmark oleh masyarakat, yaitu Musholla Ar-Raudhah. Membuat desain yang mengambil elemen-elemen dari icon yang sudah ada di Sekumpul Martapura dan mengembangkannya kembali, sehingga skywalk dapat menjadi image baru Sekumpul.

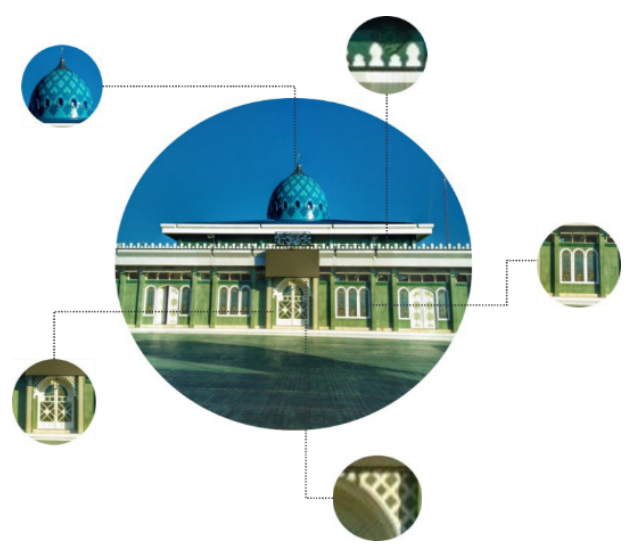

Gambar 15 Elemen Arsitektural

\section{Konsep Ruang Luar}

Konsep open space dibuat didasari oleh analisa kegiatan sehari-hari dan acara haul. Bagaimana menciptakan ruang yang dapat berfungsi menyesuaikan waktu dari kegiatan yang berlangsung. Membuat space, dengan mewadahi dan memprediksi event, yang nantinya menciptakan movement.

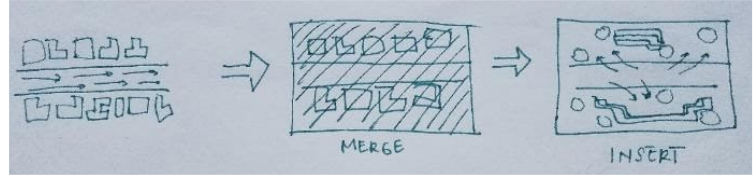

Gambar 16 Perlakuan pada Kawasan

Dengan meminjam istilah merge dan insert, yang dimaksudkan sebagaimana tertera pada tabel.

\begin{tabular}{|l|c|c|}
\hline No. & Perlakuan & Penjelasan \\
\hline 1. & Merge & Melebur tapak \\
\hline 2. & Insert & $\begin{array}{c}\text { Memasukkan } \\
\text { fungsi }\end{array}$ \\
\hline
\end{tabular}

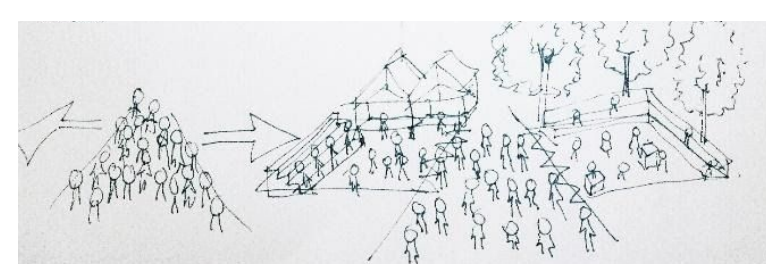

Gambar 17 Sketsa Open Space

Dengan membuat open space, fungsi lahan dapat berguna sesuai persepsi pengguna saat itu. Open space dalam kegiatan sehari-hari dapat berfungsi sebagai wadah istirahat pejalan kaki, titik kumpul pertemuan, penanda, dan wadah parkir. Namun pada acara haul, open space dapat dijadikan wadah untuk menyebar kerumunan masyarakat yang berjalan menuju satu arah yang sama.

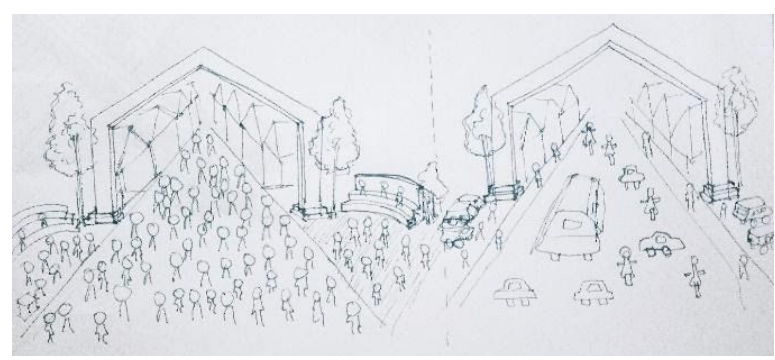

Gambar 18 Sketsa Open Space dan Gerbang

Gerbang atau portal sebagai penanda yang juga menjadi elemen sense of place yaitu legibility. Di Sekitar gerbang dibuat space yang multifungsi, menyesuaikan kegiatan dan waktu tertentu. Gambar kiri menggambarkan aktivitas pada acara haul, dan gambar kanan menggambarkan aktivitas pada hari biasa. 


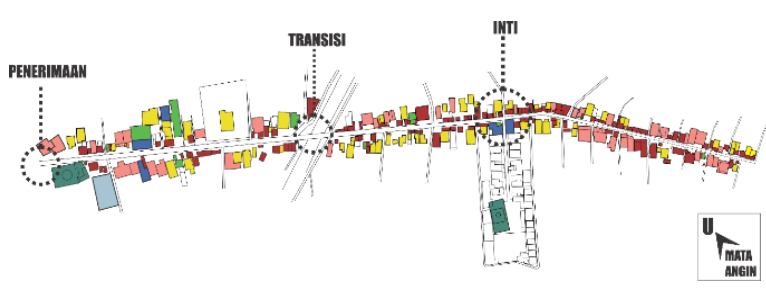

Gambar 19 Titik Penempatan Gerbang

Pedestrian yang dikhususkan untuk pejalan kaki dibedakan dalam 2 jenis, pedestrian bawah dan pedestrian atas atau skywalk. Untuk pedestrian bawah, dilakukan penataan dengan menutup drainase menjadi pedestrian. Menciptakan ruang interaksi di pedestrian, dengan penambahan street furniture seperti kursi, dan vegetasi peneduh. Sedangkan pedestrian atas dibuat khusus untuk pejalan kaki, berfungsi untuk memudahkan akses pejalan kaki saat hari biasa, dan memberi ruang tambahan untuk pengunjung haul.
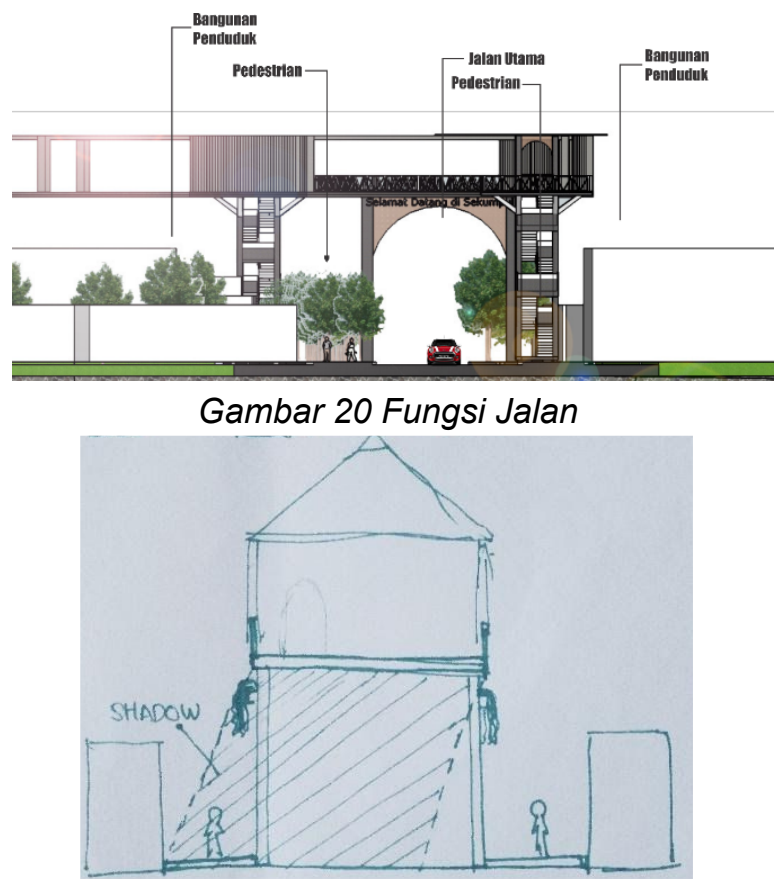

Gambar 21 Sketsa Fungsi Pedestrian

Pada jalan koridor, vegetasi didapati hanya ada kurang lebih 12 titik vegetasi peneduh, dan berdasarkan peraturan GSB adalah 15 meter dari as jalan, serta didapati titik banjir dibeberapa titik depan gang warga. Hal ini berkaitan dengan implementasi kepada desain berdasarkan solusi yang dipilih. Untuk permasalahan minimnya vegetasi, akan ditambahkan titik-titik baru vegetasi dipinggiran koridor yang menyesuaikan fungsi dan estetikanya. Untuk persoalan GSB, akan dilakukan pelebaran jalan dan penggeseran pada bangunan. Sedangkan untuk titik banjir pada jalan, dilakukan perbaikan drainase, dan pengaplikasian material yang mudah menyerap air, seperti grass block dan rumput hijau.
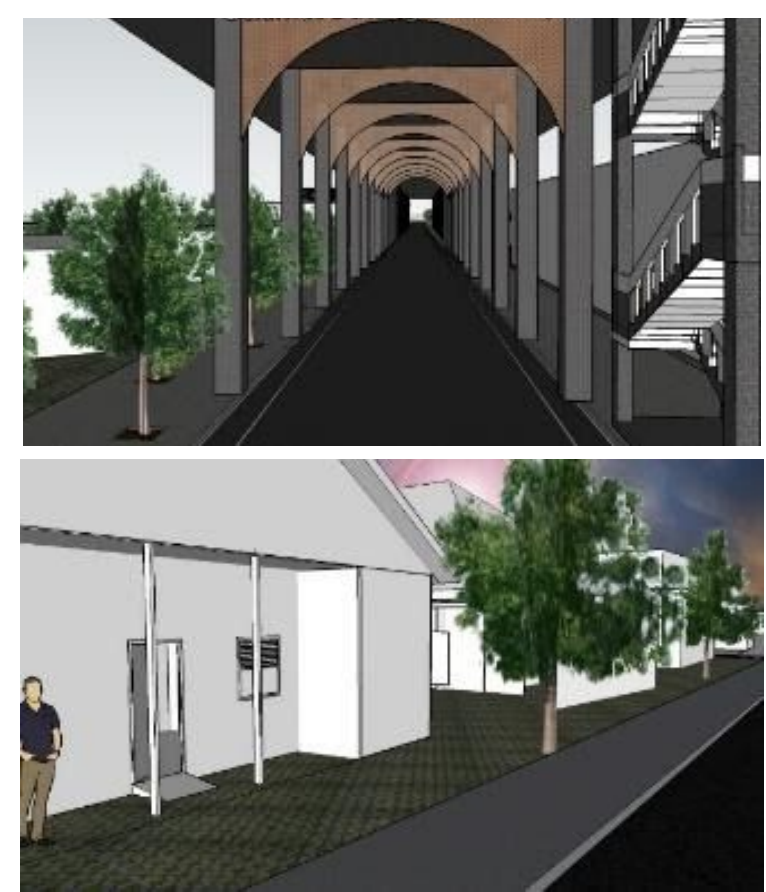

Gambar 22 Material dan Perspektif Jalan

5. Konsep Amenities

Menambah area wudhu dengan menyebar titik-titik air pada area yang ditentukan, termasuk di skywalk atau layer atas. Area wudhu dikonsep dengan memanfaatkan space-space yang bisa menjadi titik-titik kumpul dan sering dilalui yang mana mempengaruhi movement, tanpa mengganggu sirkulasi utamanya. Contohnya menggunakan tangga selain sebagai sirkulasi, namun juga area wudhu, dengan 
pengaturan movement yang sedemikian rupa. Penulis menyebut dengan istilah trigger spaces.

Dibuat open space pada segmen transisi dan inti, yang fungsinya ditentukan pada kegiatan masyarakat. Pada acara haul, open space dapat digunakan sebagai titik berkumpul atau titik point kawasan, sedangkan pada hari biasa, open space dapat dimanfaatkan sebagai lahan parkir dan titik istirahat pejalan kaki.

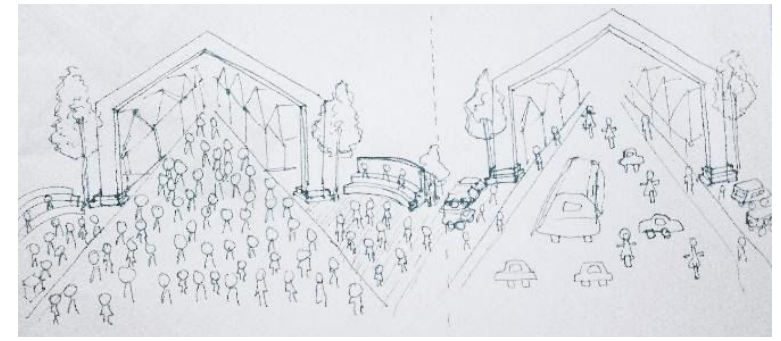

Gambar 23 Sketsa Pemanfaatan Area Parkir

6. Hasil Rancangan

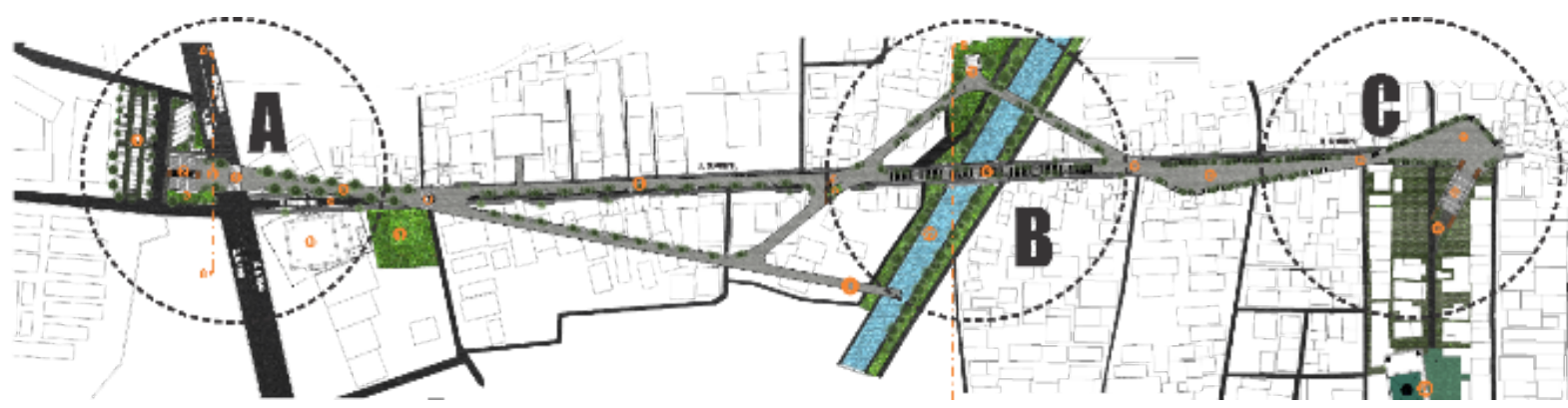

Gambar 24 Siteplan

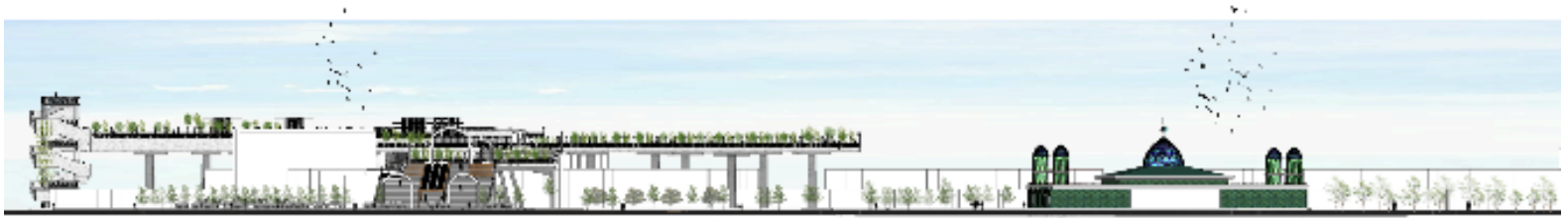

Gambar 25 Tampak Kawasan

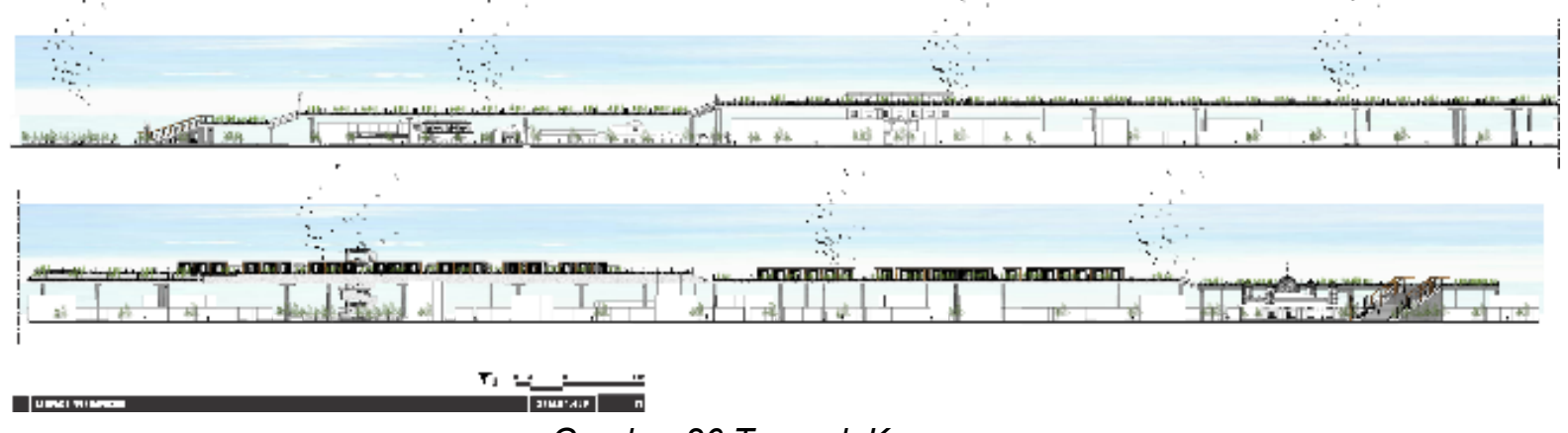

Gambar 26 Tampak Kawasan 

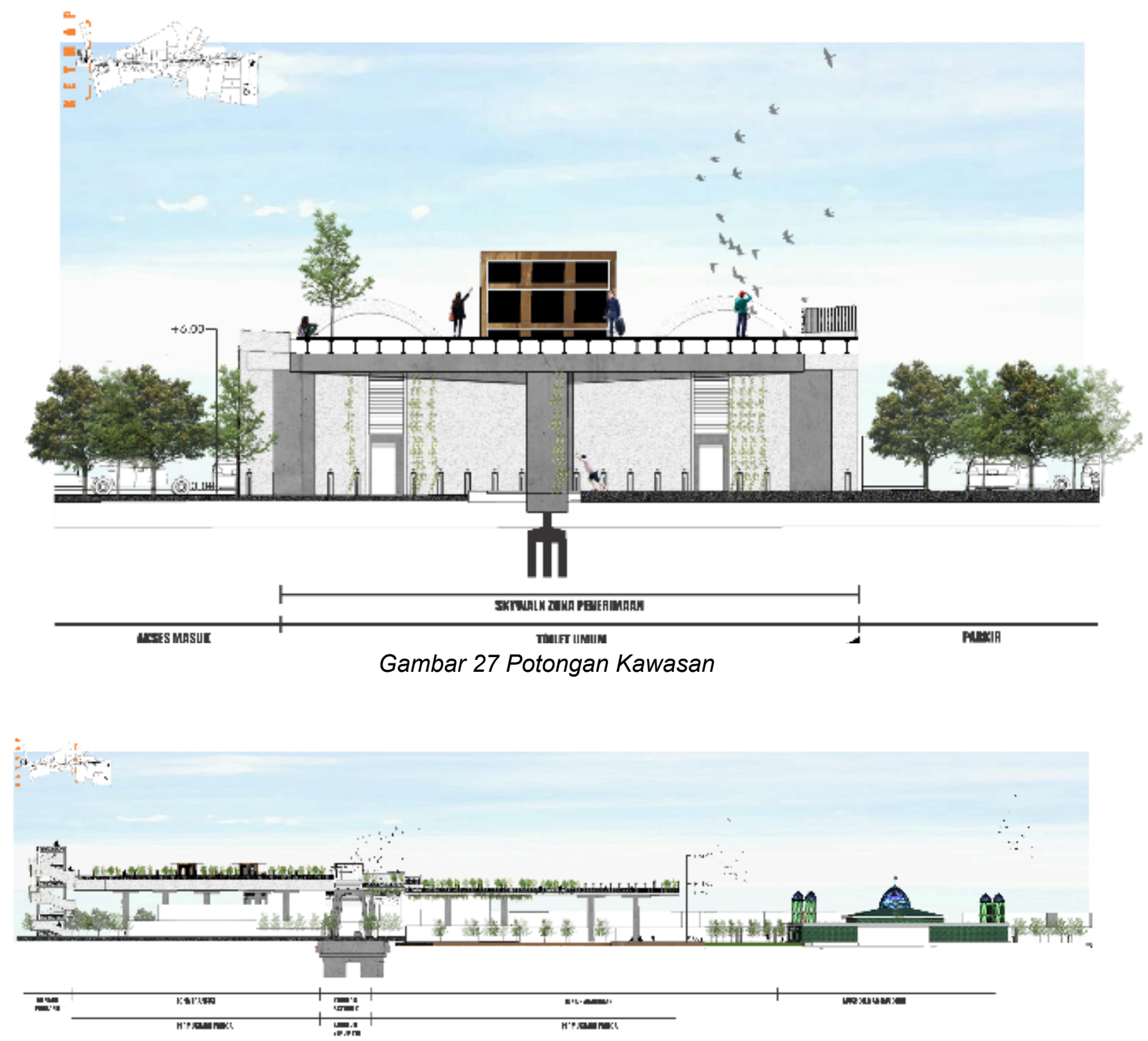

Gambar 28 Potongan Kawasan

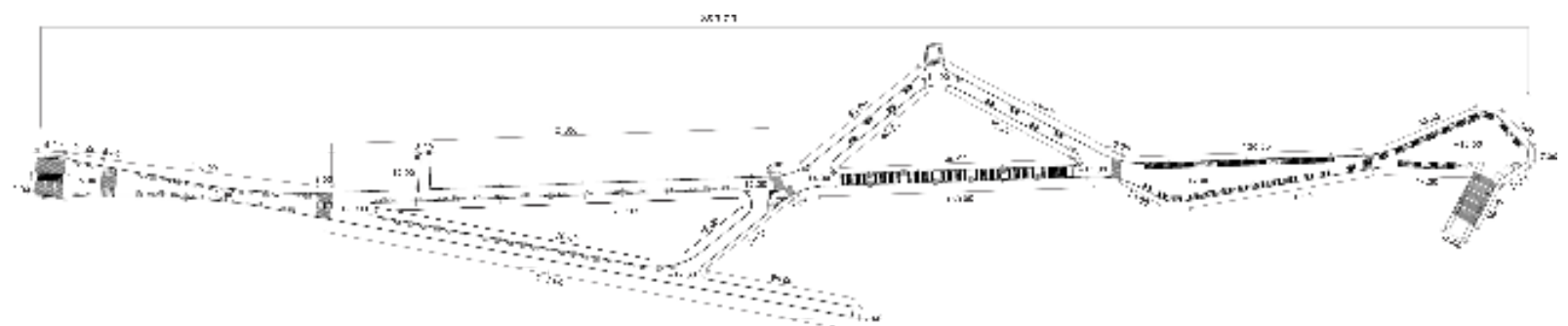

Gambar 29 Denah Skywalk 


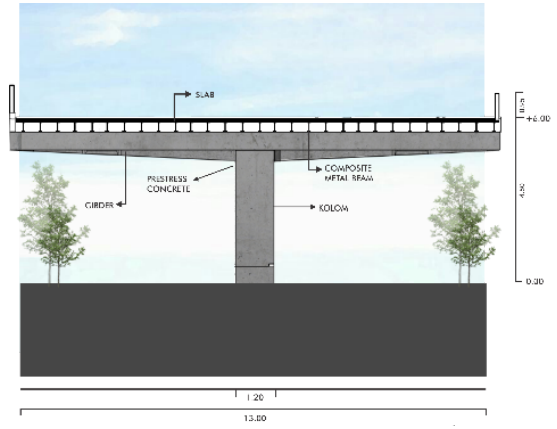

Gambar 30 Potongan Skywalk

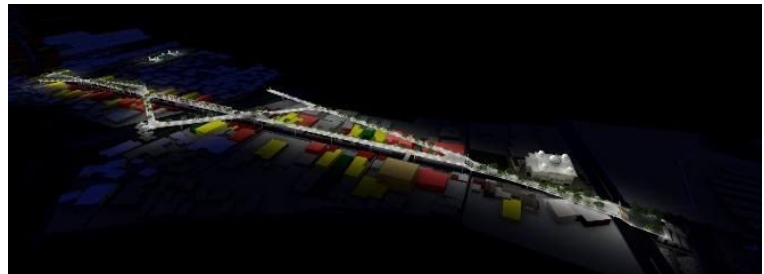

Gambar 31 Perspektif Skywalk
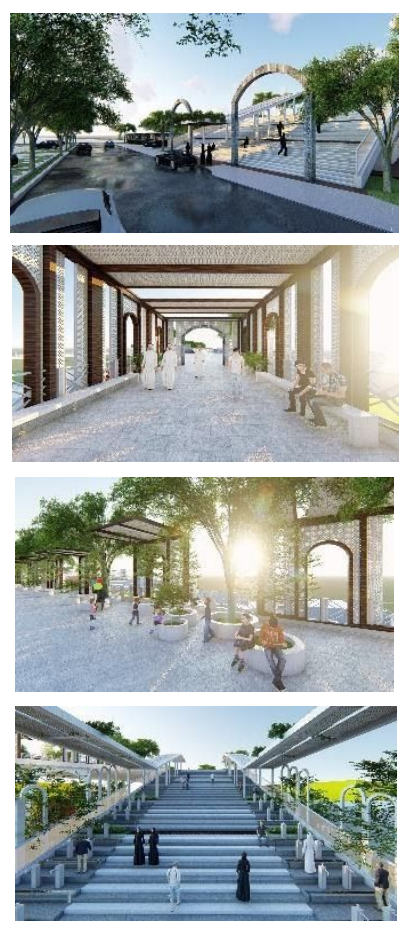

Gambar 32 Perspektif Skywalk

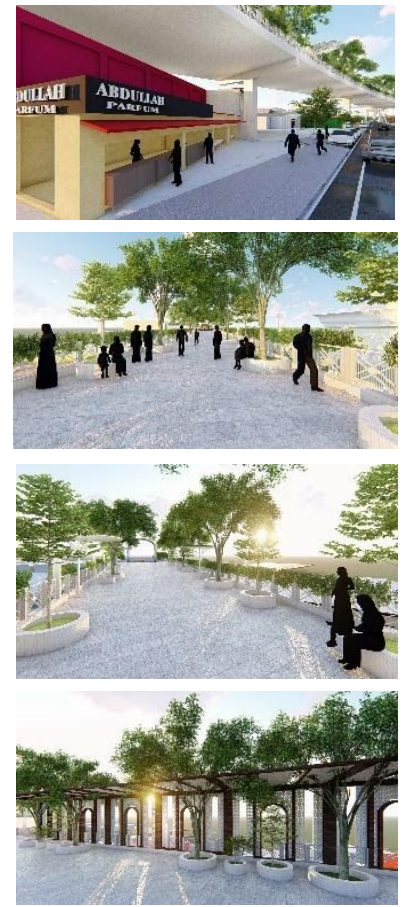

Gambar 33 Perspektif Skywalk
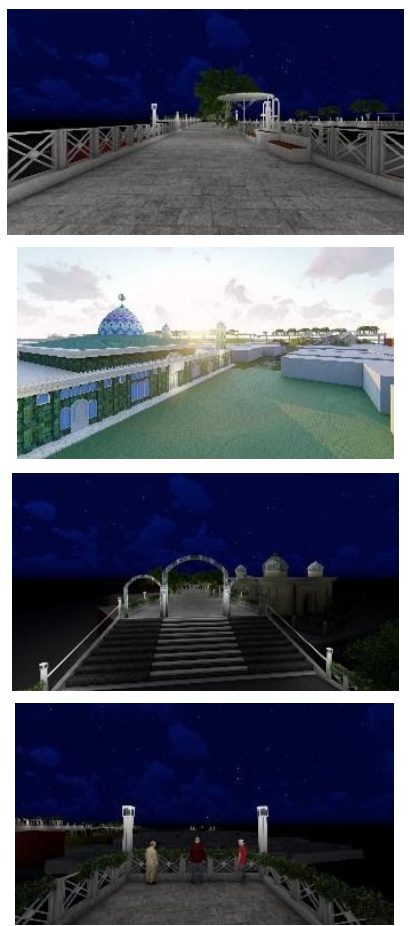

Gambar 34 Gambaran Opsi Gerbang 


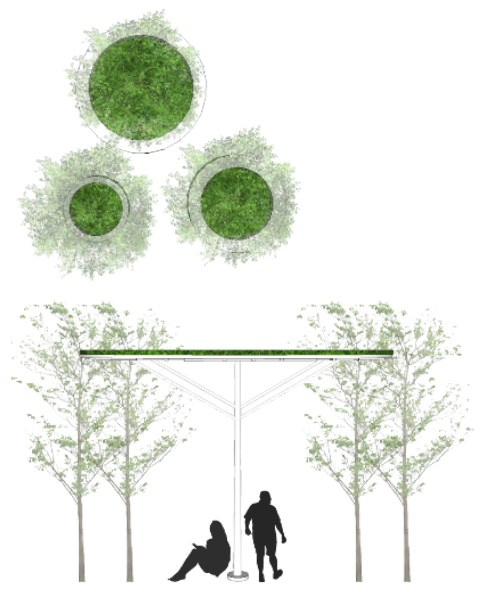

Gambar 35 Detail Lanskap

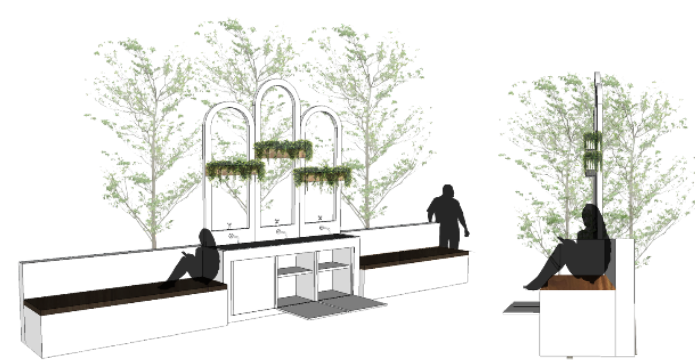

Gambar 36 Detail Lanskap
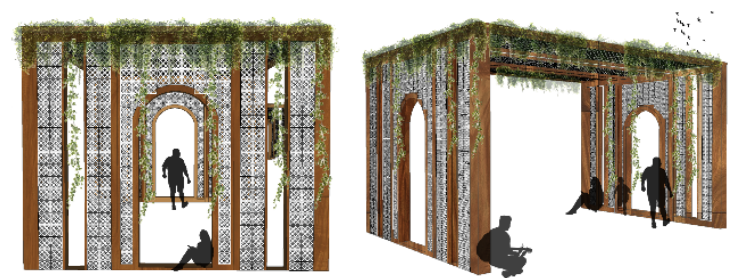

Gambar 37 Detail Lanskap

\section{KESIMPULAN}

Penataan Koridor Sekumpul Martapura membahas proses penataan Koridor Sekumpul menjadi kawasan yang lebih memprioritaskan kebutuhan pengguna sesuai dengan kebutuhannya. Penulis percaya, bahwa arsitektur bukan hanya dinilai dari segi keindahan bangunan, melainkan juga sebagai sistem yang mengatur aktivitas manusia didalamnya. Untuk dapat menyelesaikan permasalahan, penulis melakukan riset dengan observasi langsung ke lapangan, wawancara dengan penduduk setempat, dinas-dinas yang bersangkutan, dan memahami literatur-literatur baik dari buku maupun jurnal.

Dari hasil identifikasi latar belakang dan data-data yang dikumpulkan, penulis menemukan titik permasalahan arsitektural, yaitu bagaimana mengoptimalkan potensi Kawasan Sekumpul Martapura sebagai wisata religi yang memberi prioritas yang sesuai dengan kebutuhan pengguna. Korelasi dengan arsitektur adalah belum adanya perbaikan fisik kawasan yang signifikan di Kawasan Sekumpul Martapura. Maka, diangkatlah Walkable Place sebagai konsep yang pas untuk menyelesaikan permasalahan arsitektural dan mengoptimalkan potensi kawasan. Tingkat antusias pengunjung yang tinggi saat Haul Guru Sekumpul dan kegiatan pada hari-hari biasa turut menjadi pertimbangan. Untuk mencapai hal tersebut, digunakanlah metode sense of place, dengan menerapkan beberapa elemennya dari aspek form, activities dan image.

Sebelum itu, dilakukan analisis dengan menggunakan teori sense of place itu sendiri. Analisis form, yang berisi konteks kawasan, tata guna lahan, massa bangunan, aksesibilitas, garis sempadan bangunan, struktur jalan, jalan pedestrian, volume lalu lintas, dan analisis signage. Yang kedua analisis makna atau citra kawasan Sekumpul yang kuat sebagai kawasan religi, dan analisis activity yang berisi analisis activity support, aktivitas ibadah, dan ruang sosial. Setelahnya diperdalam dengan analisis hasil survey dan wawancara, memuat apa yang dirasakan dan harapan warga pengguna Jalan Sekumpul, selanjutnya diikuti analisis fungsi yang menganalisa aktivitas penduduk secara lebih detail, seperti aktivitas yang dominan 
dilakukan warga, apa yang mereka jual, sampai alat transportasi yang digunakan masyarakat, dan terakhir, analisis utilitas yang membahas sistem listrik, air bersih, air kotor dan sampah di Sekumpul Martapura.

Setelah melalui proses analisis, pencarian output dan implementasinya, diharapkan Penataan Koridor Sekumpul Martapura Sebagai Wisata Religi ini dapat memberi solusi dan strategi arsitektural yang menjawab permasalahan di Sekumpul Martapura.

\section{DAFTAR PUSTAKA}

Agustin, I. W. (2017). Penerapan Konsep Walkability di Kawasan Alun-alun Kota Malang. Jurnal Pengembangan Kota, 5(1): 45-57.

Forsyth, A. (2008). Cities Afoot-Pedestrians, Walkability and Urban Design. Journal of Urban Design, 13(1): 1-3.

Forsyth, A. (2015). What is a Walkable Place? The Walkability Debate in Urban Design. Urban Design International, 20(4): 274-292.

Latifah, N., Soemardiono, B. dan M. Faqih. 2018. The Arrangement Of Religious Tourism Corridor In Sekumpul Martapura Based On Livable Street. International Journal of Scientific and Research Publications, 8(7): 459-464.

Moughtin, C. (1992). Urban Design: Street and Square. Madison: University of Wisconsin.

Purwantiasning, A. W., F. Masruroh dan Nurhidayah. (2013). Analisa Kawasan Boat Quay Berdasarkan Teori Kevin Lynch. Jurnal Arsitektur UMJ NALARs, 12(1).

Sihite, R. 2000. Tourism Industry (Kepariwisataan). Surabaya: Penerbit SIC.

Pendit, Nyoman S. (2003). Ilmu Pariwisata Sebuah Pengantar Perdana. Jakarta: PT. Pradnya Paramitha.
Zuhri, M. (2012). Aspek Hukum Perencanaan Tata Ruang Kawasan Perkotaan Kanun. Jurnal IImu Hukum, 58: 485-494. 